\title{
Rethinking advertising policy in light of the climate crisis
}

institucionales.us.es/ambitos/

\section{David J. Park}

Florida International University

djpark@fiu.edu

There is a significant need for a paradigm shift in advertising and climate change scholarship. While content- and consumer-based work in advertising is useful, especially in terms of creating messages to target deniers of global warming (Atkinson, 2017), it is limited in its ability to directly assist with climate change mitigation. Reimagining advertising systems as gatekeepers, that distribute advertisements under conditions that take into account production processes, may be able to make up for this limitation.

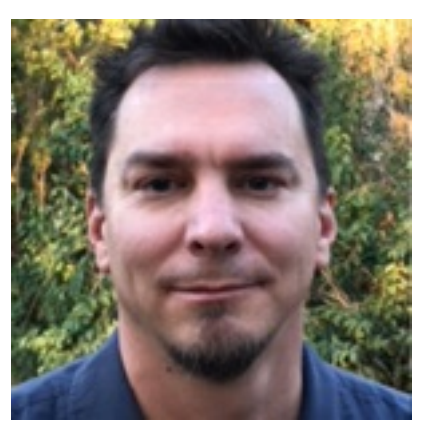
Rethinking the manner in which advertising transactions occur in order to advertise in media, by moving them away from strict business and financial exchange interpretations, to a new exchange system also based on environmental concerns, may be the most effective contribution to climate change mitigation the field of communication can offer. There is limited time left to reverse the direction before dangerous, potentially irreversible changes in the Earth's climate occur (Anderson, 2012; Foster, 2017).

Before the transition to capitalism, advertising was almost non-existent, while excess and consumerism were mostly eschewed (Dyer, 1982). During this period, the impact of advertising on economic performance was minimal, and human-made carbon dioxide emissions were too low to significantly

ÁMBITOS 2018 $n=40$ damage the planet. This dramatically changed with the transition to capitalism and the various stages of the industrial revolution. Advertising became an integral part of the new system of production. The manner in which capitalism viewed and interacted with nature, mostly through domination and subjugation (Cook, 2011; Gunderson, 2015), shaped the way in which advertising would eventually interact with nature. In essence, capitalism subsumed advertising to reflect its existent relationship with nature (Holm, 2017), which meant that advertising transactions were primarily defined in business terms that ignored societal and/or environmental ramifications. Under this arrangement, advertising transactions became oblivious to the non-commercial consequences of their mode of operation and ignored both the pre and post-advertising stages of products or services that were advertised. Promoting overconsumption along with products and services with environmentally unsustainable modes of production meant that advertising would help widen the metabolic rift with the Earth and significantly contribute to the ecological crisis (Baran \& Sweezy, 2013; Corbett, 2002; Jhally, 1997; Morgan, 2015; Schutz, 2011; Shapiro, 2014). 
It's now time to reverse this arrangement. Because capitalism is at odds with planetary sustainability (Foster, 2017; Klein, 2014), building a new advertising system will require scholars to think outside of the boundaries created by capitalism. While Foster (2017) argues there is a need to turn to the social sciences to "understand the social causes of climate change, and the necessary solutions" (p. 93), he also points out that much of the work in the social sciences is compromised and ideologically compelled to address issues in terms set by capitalism, which excludes most perspectives that challenge that system or its boundaries.

Examining advertising outside of this context is quite challenging as the field is polarized between industry-oriented academics whose research is often administrative, and, at the fringes, critical scholars who see advertising as an extension of capitalism and therefore conceptualize it without positive agency. For the most part, while advertising is seen as a powerful tool that can create demand to increase consumption to meet capitalist production (Dyer, 1982; Faraone, 2011; McChesney, 2004; Galbraith, 1969), most critical scholars have yet to see its potential power to meet the demands of alternative production models based on environmental sustainability or its ability to help transition out of capitalism. This assumption limits propensities to reimagine what an advertising system could look like if it wasn't subsumed under capitalism. It also limits abilities to harness and reverse the power of the current advertising distribution and transactional systems for environmental mitigation purposes.

According to Foster (2017), the "danger to the planetary environment posed by the accumulation of capital is all-encompassing. This means that the ecological revolution will have to extend eventually to the roots of production itself" (p. 110). An advertising policy that addresses modes of production for products and services would go a long way as an incentive for manufacturers to change their behavior. It may even assist in the overall transformation away from an exploitative and unequal economy toward a new system based on a more harmonious relationship with nature and human development. In this sense, advertising can be viewed as a powerful mechanism within a system. Moreover, adjusting it has the potential to significantly redefine the nature and direction of that system.

It's time to divorce advertising from its harmful relationship with capitalism and nature so that it can be used to help reverse the trajectory of the climate crisis. There is a need for advertising scholarship to image a new system of advertising policies that can pressure industries to transition their production processes to create more environmentally sustainable products and services. The questions become: what will new advertising distribution systems look like? How will they be regulated? Will they be limited to environmental issues, or will they also address social and psychological concerns? How would such a system do this?

While there is little doubt advertising assisted the overall process that created global warming, it also has immense power and potential to help propel the planet out of the present climate crisis. It is merely a tool and we can define it how we want it to work for humanity. Using the advertising system as a gatekeeper, perhaps starting with significant fees for products and services that excessively contribute to global warming, may be the most useful and effective way the field of communication can contribute to mitigating climate crisis. 


\section{References}

Anderson, K. (2012). Climatechangegoingbeyonddangerous - Brutalnumbers and tenuoushope.Development Dialogue, 61,16-40.

Atkinson, L. (2017). Portrayal and impacts of climate change in advertising and consumer campaigns. Oxford Research Encyclopedias. DOI:

10.1093/acrefore/9780190228620.013.376

Baran, P. \& Sweezy, P. (2013). Theses on advertising. Monthly Review,65(3), pp. 34-42.

Cook, D., 2011. Adorno on nature. Durham, NC: Acumen.

Corbett, J. B. (2002). A faint green sell: Advertising and the natural world. In M. Meister \& P. M. Japp (Eds.), Enviropop: Studies in environmental rhetoric and popular culture (pp. 141-160). Westport, CT.: Praeger Publishers.

Dyer, G. (1982). Advertising as communication. New York: Methuen \& Co.

Faraone, R. (2011). Economy, ideology, and advertising. In J. Wasco, G.

Murdock \& H. Sousa (Eds.), The handbook of political economy of communications (pp. 187-205).Oxford: Blackwell Publishing

Foster, J. B. (2017). Trump in the White House: Tragedy and farce. New York: Monthly Review Press.

Galbraith, J. (1969). The affluent society. Boston: Houghton Mifflin Company.

Gunderson, R.(2015). Environmental sociology and the Frankfurt School 1:

Reason and capital. Environmental Sociology, 1(3), pp.224-235.

Holm, N. (2017). Art for fun and profit: The political aesthetics of advertising. In J.

Hamilton, R. Bodle, \& E. Korin (Eds.), Explorations in critical studies of advertising (pp. 97109). New York: Routledge.

Jhally, S. (1997). Advertising and the end of the world: The Movie. PDF Transcript. Media Education Foundation. Retrieved from https://www.mediaed.org/assets/products/101/transcript_101.pdf

Klein, N. (2014). This changes everything: Capitalism versus the climate. New York: Simon \& Schuster.

McChesney, R. W. (2004). The problem of the media. New York: Monthly Review Press.

Morgan, T., 2015. Growing ourselves to Death? Economic and ecological crises, the growth of waste, and the role of the media and cultural industries. Human Geography, 8(1), pp. 68-81. 
Northrup, C. C. (2003). The American economy. Santa Barbara: ABC-CLIO, Inc. Park, D. (2017). Toward an ecological critique of advertising. In J. Hamilton, R.

Bodle, \& E. Korin (Eds.), Explorations in Critical Studies of Advertising (pp. 67-80). New York, NY: Routledge.

Schutz, E. (2011). Inequality and power: The economics of class. New York:

Routledge.

Shapiro, S. (2014). Poor people, poor planet: The psychology of how we harm and heal humanity and Earth. In E. Mustakova-Possardt, M. Lyubansky, M. Basseches \& J. Oxenberg (Eds.), Toward a socially responsible psychology for a global era (pp. 231-254). New York: Springer.

(1) Advertising content is irrelevant and external to this paper. Instead, the focus is on the transactions and advertising distribution systems. Transactions occur when people or organizations purchase advertising. Distribution occurs when an organization or communication medium then publishes the advertisement within its media outlets. In this sense, the transaction process is the gate-keeping function that allows advertising to be distributed in media.

(2) Of course not every advertising campaign works, and not everyone consumes products after they view an advertisement. That said, there is a strong relationship between advertising, economic performance and consumption. For example, during the industrial revolution, advertising became increasingly important in terms of developing and expanding new business markets (Northrup, 2003), which significantly assisted in the development of consumer economies (Park, 2017). In sum, advertising can increase economic growth by stimulating spending, consumption, production and investment opportunities (Baran \& Sweezy, 2013).

\section{BREVE SEMBLANZA DEL AUTOR:}

David J. Park. Associate Professor (Florida International University)

Ámbitos. Revista Internacional de Comunicación, n.40, edición de primavera, 2018. 